\title{
Administration of routine preventative vaccinations in children with polyarticular juvenile idiopathic arthritis receiving adalimumab
}

\author{
Kirsten Minden ${ }^{1 *}$, Mahinda Karunaratne ${ }^{2}$, Hartmut Kupper ${ }^{3}$, Jasmina Kalabic ${ }^{3}$ \\ From 21st European Pediatric Rheumatology (PReS) Congress \\ Belgrade, Serbia. 17-21 September 2014
}

\section{Introduction}

Adalimumab (ADA) has been shown to be safe and effective in polyarticular juvenile idiopathic arthritis (pJIA), and is approved for use in moderate to severe pJIA patients (pts) $\geq 4$ years (yrs) in the US, Australia, and Japan, and in the EU for pts $\geq 2$ yrs.

\section{Objectives}

This post hoc report describes the observed use of vaccines in pJIA pts receiving ADA in 3 clinical trials and one registry.

\section{Methods}

Pts with active pJIA were enrolled in one of the following trials: M10-444 (ages 2 to $<4$ or $\geq 4$ weighing $<15 \mathrm{~kg}$ in US, EU), M10-240 (ages 4-17 in Japan), DE038 (ages 4-17 in US, EU) or the STRIVE (P10-262) registry (ages 4-17 in US, EU, and Australia). Pts received ADA \pm methotrexate. Vaccinations were administered based on the judgment of the study investigator or the treating physician. Descriptive statistics were used to summarize all vaccinations. Adverse events (AEs) related to active influenza virus infection events occurring within 270 days after influenza vaccination were collected by a predefined MedDRA query 15.1 [Lack of efficacy/effect Influenza (Vaccination Product Specific)].

\section{Results}

The influenza vaccine was the most frequently administered: 55, 63, 10 and 22 influenza vaccines were administered in DE038, M10-240, M10-444 and P10-262, respectively. In addition, pneumococcal, human

${ }^{1}$ Kinderklinik der Charite, Otto-Heubner Centrum, Berlin, Germany Full list of author information is available at the end of the article papilloma virus, diphtheria, tetanus and/or pertussis, hepatitis $\mathrm{A}$ and $\mathrm{B}$, and polio vaccines were administered. 2 pts each received $>5$ vaccinations in DE038 and M10240, while 3 pts each in M10-444 and P10-262 received $>1$ but $<5$ vaccinations. The influenza vaccine was administered to $32 / 171$ (19\%), 20/25 (80\%), 6/32 (19\%) and $21 / 533$ (4\%) of pts during the course of the study in DE038, M10-240, M10-444 and P10-262 respectively, and the mean (SD) time to 1 st influenza vaccination while pts were on ADA was high: 675 (618), 189 (80), 93 (90) and 443 (396) days. The rates of influenzarelated AEs reported for pts who received influenza vaccinations and those who did not were: $13 \%$ vs $9 \%$ for DE038, $15 \%$ vs $20 \%$ for M10-240, $0 \%$ vs $12 \%$ for M10444, and $5 \%$ vs $0.4 \%$ for P10-262. Table 1.

\section{Conclusion}

These data support the idea that pJIA pts treated with ADA can be immunized with routine, inactive, preventative vaccines. Not all of the eligible pts were vaccinated

\section{Table 1}

\begin{tabular}{|c|c|c|c|c|}
\hline All Vaccinations & DE038 & $\begin{array}{c}\text { M10- } \\
240\end{array}$ & $\begin{array}{c}\text { M10- } \\
444\end{array}$ & $\begin{array}{l}\text { P10- } \\
262\end{array}$ \\
\hline Total patients vaccinated, $\mathrm{n} / \mathrm{N}$ & $38 / 171$ & $20 / 25$ & $6 / 32$ & $22 / 533$ \\
\hline Mean age, yrs (SD) & $\begin{array}{l}11.8 \\
(3.6)\end{array}$ & $\begin{array}{l}13.6 \\
(3.3)\end{array}$ & $3.0(0.7)$ & $\begin{array}{l}12.7 \\
(4.0)\end{array}$ \\
\hline Total vaccinations, $\mathrm{n}$ & 77 & 64 & 10 & 25 \\
\hline $\begin{array}{l}\text { Patients with }>1 \text { type of } \\
\text { vaccination, } n\end{array}$ & 11 & 1 & 0 & 2 \\
\hline Different types of vaccinations, $n$ & 9 & 2 & 1 & 4 \\
\hline $\begin{array}{l}\text { Mean time to } 1^{\text {st }} \text { vaccination*, } \\
\text { days }\end{array}$ & 688 & 189 & 93 & 448 \\
\hline Mean age at $1^{\text {st }}$ vaccination*, yrs & 12.9 & 14.0 & 3.6 & 12.0 \\
\hline
\end{tabular}

(c) 2014 Minden et al; licensee BioMed Central Ltd. This is an Open Access article distributed under the terms of the Creative Commons Attribution License (http://creativecommons.org/licenses/by/4.0), which permits unrestricted use, distribution, and reproduction in any medium, provided the original work is properly cited. The Creative Commons Public Domain Dedication waiver (http:// creativecommons.org/publicdomain/zero/1.0/) applies to the data made available in this article, unless otherwise stated. 
on time according to the Centers of Disease Control (CDC) recommendations, and many pts were not vaccinated at all, suggesting that physicians may be reluctant to use vaccines in children receiving antirheumatic therapies. Further investigation of vaccination practices for pts with JIA is warranted.

\section{Trial registration identifying numbers}

NCT00774537, NCT00690573, NCT00048542 and

NCT00783510

\section{Disclosure of interest}

K. Minden Grant / Research Support from: AbbVie, Pfizer, Consultant for: Pfizer, AbbVie, Roche/Chugai, Novartis, Medac, Pharm-Allergan, Speaker Bureau of: Pfizer, AbbVie, Roche/Chugai, Novartis, Medac, PharmAllergan, M. Karunaratne Shareholder of: AbbVie, Employee of: AbbVie, H. Kupper Shareholder of: AbbVie, Employee of: AbbVie, J. Kalabic Shareholder of: AbbVie, Employee of: AbbVie

\section{Authors' details}

'Kinderklinik der Charite, Otto-Heubner Centrum, Berlin, Germany. ${ }^{2}$ AbbVie Inc, North Chicago, United States. ${ }^{3}$ AbbVie Deutschland GmbH \& Co. KG,

Ludwigshafen, Germany.

Published: 17 September 2014

doi:10.1186/1546-0096-12-S1-P20

Cite this article as: Minden et al:: Administration of routine preventative vaccinations in children with polyarticular juvenile idiopathic arthritis receiving adalimumab. Pediatric Rheumatology 2014 12(Suppl 1):P20.
Submit your next manuscript to BioMed Central and take full advantage of:

- Convenient online submission

- Thorough peer review

- No space constraints or color figure charges

- Immediate publication on acceptance

- Inclusion in PubMed, CAS, Scopus and Google Scholar

- Research which is freely available for redistribution

Submit your manuscript at www.biomedcentral.com/submit 